\title{
Quality of Work-Life for Job Satisfaction in Nepalese Commercial Banks
}

\author{
Pitri Raj Adhikari*
}

\begin{abstract}
This paper is concerned with the examination of the impact of quality of work life for job satisfaction in Nepalese commercial banks. To achieve the purpose of the study, structured questionnaire is prepared and collected from 225 respondents. Descriptive and casual comparative research design have been used in this study. The multiple regression model has been used to test the relationship. The results show that working environment, work life balance, compensation and reward, training and development, and job design are positively related to job satisfaction. The regression result shows that the beta coefficients for all variables are positive and significant with job satisfaction.
\end{abstract}

Keywords: Work life balance, training and development, compensation and reward, working environment, job design, job satisfaction.

Paper Type: Research Paper

\section{Introduction}

Job satisfaction has been one of researchable issue for researchers and practitioners for last few decades. Prior research has linked job satisfaction with different predictors. Among them, quality of work life (QWL) which is essential for organizations to continuously attract and retain employees, is one of the important predictors. It has found different consequences of QWL among them job satisfaction is one of the important outcomes of QWL. Job satisfaction is crucial for better performance of organizations. Furthermore, to achieve organizational effectiveness, there is need to address the employee needs, particularly on aspects such as quality of work life which have impact on employees' job satisfaction and their performance (Muindi \& Obonyo, 2015). Akdere (2006) stated the quality of work life has become critical due to the increasing demands of today's business environment and family structure. Quality of work life is a comprehensive concept which consists of physical and psychological health, economic situations, personal belief and interaction with the environment (Khorsandi et al., 2010). Similarly, Mirkamali and Sani, (2008) revealed that meaning of quality of work life is subjective imagination and the perception of organizational personnel about the physical and

* Mr. Adhikari is Lecturer at Tribhuvan University, Faculty of Management, Shanker Dev Campus Email:mailtoadhikari@gmail.com 
the psychological desirability of work environment and their work situations. Quality of work life helps to reduce absenteeism, lower turnover of employee and improve job satisfaction of employees in the organization (Yavari et al. 2009). In addition, Lau (2000) examined that service organizations that emphasize on QWL for their employees have better sales growth, asset growth, and return on asset growth (ROAG) over a five-year period. Therefore, the quality of work life also leads to improved organizational performance. Ganguly (2010) concluded that quality of work life positively and significantly contributes towards increasing satisfaction experienced by the employees in their concerned job. Tabassum (2012) showed that all aspects of quality or work life, i.e. compensation, working conditions, job security, social integration, work life balance, social relevance of work life have a positive relationship with job satisfaction. The extrinsic determinants of quality of work life like pay, benefits, supervisory style plays a major role in job satisfaction (Lewis et al., 2001).

Royuela et al. (2009) stated that the quality of work life is one of the most important factors for human motivating and improving job satisfaction. Quality of work life is the favorableness of a job environment for people who refer to the quality of relationship between employees and the total working environment. According to Harrison (1985), quality of work life is the degree to which the working organization contributes to the material and psychological well-being of its members. Golkar (2013) revealed that good quality of work life can increase job satisfaction and job performance, reduce absenteeism and increase organizational effectiveness and organizational commitment.

Inflexible working hours, lack of work-family balance, management behavior, short vacation, and lack of facilities led to higher levels of dissatisfaction regarding the quality of work life among nurses (Almalki et al. 2012). Compensation and reward, good opportunity for growth, work load, job security, and clarity of policies have a significant and positive impact on job satisfaction (Almarshad, 2015). Yaseen (2013) revealed that people expect that their performance will increase and automatically their pay will increase and they will be promoted if they work well in the workplace. Similarly, Fourie (2004) explained that there is a significant relationship between the dimensions of the quality work life and the employees' job satisfaction. In addition, the study investigated that the dimension of organizational climate among the dimension of quality of work life is the most important one in prediction of job satisfaction.

However, Fatah et al. (2011) found that there is no significant relationship of the components i.e. fair and adequate payment, legalism of work environment and human capabilities with the job satisfaction of employees. In contrast, Hodgetts and Hegar (2005) stated that job design is an important issue in human relations. Costen and Salazar (2011) revealed that employees who perceive they have the opportunity to develop new skills through training and development programs are satisfied with their jobs and are more loyal and likely to stay within the organizations. However, Black and Lynch (2001) found that there is no significant impact of training on performance and job satisfaction of employees or only a deferred impact. 
Tabassum et al. (2011) revealed the factors of QWL as adequate and fair compensation, work and total life space, opportunity to develop human capacities, flexible work schedule and job assignment, and employee relations. However, Tabassum et al. concluded that there is a significant difference between the local private and foreign commercial bank's employees' perception over QWL in above mentioned factors. However, Kaur (2010) found that flexible management is positively related to job satisfaction.

Shrestha (2006) revealed that work-related satisfaction of employees is highly correlated with the work environment. Thus, when employees are satisfied with their jobs, it will lead to improved and increased employee performance and productivity. Adhikari and Gautam (2011) also argued for making the work environment motivating and interesting to boost employee performance in the organization. Biswakarma (2015) stated that the quality of work life is positively and significantly associated with employee job satisfaction. Employees working in non- financial sectors were found more satisfied with quality of work life than the employees working in financial sectors. It is also revealed that workplace conditions and employee engagement are congenial in non-financial sector in Nepal.

This paper examines the impact of job design, compensation and reward, work life balance, training and development and working environment on employee job satisfaction in Nepalese commercial banks. Moreover, research has been done concerning to QWL and job satisfaction in western context; however, there are very few research has been done in the context of Nepal. Hence, the study attempts to examine the linkage between quality of work life and job satisfaction in Nepalese context.

\section{Operational Definitions and Hypotheses}

\section{Working Environment and Job Satisfaction}

Working environment was measured using a 5-item scale. The respondents were asked to indicate the level of agreement or disagreement on the physical environment of their organization on a 5 -point Likert scale ( $1=$ strongly disagree to $5=$ strongly agree). Sample items include "Bank has good working environment." and "Bank is able to maintain a healthy balance between work and family life." The reliability of the construction of the job satisfaction was measured by the Cronbach's alpha $(\alpha=0.87)$. Gerhart and Milkovich (1990) found that working environment is positively related to the job satisfaction. Similarly, Khan and Mishra (2013) revealed a positive relationship between the working environment and healthy balance between work and family life. Employees who have good working environment are usually more satisfied, less likely to leave, more productive, more likely to display employee commitment, and more likely to be satisfied with their lives (Lease, 1998). Based on it, this paper develops following hypothesis:

$\mathrm{H}_{1}$ : There is a positive relationship between working environment and employees' job satisfaction. 


\section{Work Life Balance and Job Satisfaction}

Work life balance was measured using a 5-item scale. The respondents were asked to indicate the level of agreement or disagreement on the physical environment of their organization on a 5 -point Likert scale $(1=$ strongly disagree to $5=$ strongly agree). Sample items include "Employee relations in my organization are source of motivation to employee." and "I feel I am able to balance work life." The reliability of the construction of the job satisfaction was measured by the Cronbach's alpha $(\alpha=0.89)$. Greenhaus (2002) defined work -life balance as satisfaction and good functioning at work and at home with a minimum of role conflict. According to Paul Krassner (1995), the results observed that anthropologists define happiness as having as little separation as possible between your work and your play. Different work life balance experiences have a significant impact on the job satisfaction of employees (Adikaram and Jayatilake, 2016). Similarly, the study has found that work-life balance has a positive impact on job satisfaction (Anuradha \& Pandey, 2016). Based on it, this study develops the following hypothesis:

$\mathrm{H}_{2}$ : There is a positive relationship between work life balance and employee satisfaction.

\section{Compensation and Reward, and Job Satisfaction}

Compensation and reward were measured using a 5-item scale. The respondents were asked to indicate the level of agreement or disagreement on the physical environment of their organization on a 5 -point Likert scale ( $1=$ strongly disagree to $5=$ strongly agree). Sample items include "Bank provides the compensation fairly." and "Bank provides the reward based on performance appraisal of employees." The reliability of the construction of the job satisfaction was measured by the Cronbach's alpha $(\alpha=0.92)$. Compensation is a fundamental component of human resource management. It covers economic reward in the form of wages and salaries as well as benefits, indirect compensation or supplementary pay (Ojo, 1998). Likewise, compensation package has great effect on employee performance (Aslam et al., 2015). Compensation emanates basically from the fact that it provides income to workers and constitutes an important cost item to the employer (Martocchio, 2011) and hence, there is positive relationship between compensation and reward, and job satisfaction. Based on it, this paper develops the following hypothesis:

$\mathrm{H}_{3}$ : There is a negative relationship between compensation and reward and employees job satisfaction.

\section{Training and Development, and Job Satisfaction}

Training and development was measured using a 5-item scale. The respondents were asked to indicate the level of agreement or disagreement on the physical environment of their organization on a 5 -point Likert scale $(1=$ strongly disagree to $5=$ strongly agree). Sample 
items include "I am satisfied with the training and development program organized by the bank" and "Bank provides training according to the need assessment of employees." The reliability of the construction of the job satisfaction was measured by the Cronbach's alpha ( $a$ $=0.95$ ). Training and development programs create awareness among employees for using of new technology (Imran et al., 2014). In addition, training and development is significantly correlated with job satisfaction (Anwar \& Shukur, 2015).Training and development will lead to higher job satisfaction level in employees and they will fulfill their duties with a great deal of responsibility with best performance. The finding of our study showed positive impact of training and development and job satisfaction with employee performance (Khan et al., 2016). Based on it, the study develops the following hypothesis:

$H_{4}$ : There is a negative relationship between compensation and reward, and employees' job satisfaction.

\section{Job Design and Job Satisfaction}

Job design was measured using a 5-item scale. The respondents were asked to indicate the level of agreement or disagreement on the physical environment of their organization on a 5-point Likert scale $(1=$ strongly disagree to $5=$ strongly agree). Sample items include "Use social networking sites provide me with opportunities to learn new skill" and "I get information about free training webinar and skill development program using social networking sites" The reliability of the construction of the job satisfaction was measured by the Cronbach's alpha ( $\alpha=0.89$ ). Parker (2010) defined the aim of a job design is to improve job satisfaction, to improve through-put, to improve quality and to reduce employee problems. The results concluded that there is a strong positive correlation between job design and employee satisfaction and both of these variables move in the same direction (Abid et al., 2013). The various psychological literatures on employee motivation claimed that changes in job design can produce better employee job performance and job satisfaction - Lawler (1969). Based on it, this study develops the following hypothesis:

$H_{5}$ : There is a positive relationship between job design and employees job satisfaction.

\section{Methods}

This paper is based on the primary data which were gathered from 225 respondents of 25 Nepalese commercial banks. The respondents' views were collected on innovative behavior, turnover intention, absenteeism, job satisfaction, communication, knowledge sharing, and employee job performance and employee commitment.

\section{The model}

The model estimated in this study assumes that the linkage between quality of work life and employee job satisfaction depends upon different factors. In this model, the dependent variable is employee job satisfaction in Nepalese commercial banks. The independent variables are job design, learning and development, work-life balance, compensation and 
rewards, and workplace environment. Therefore, the following model equation is designed to test the hypothesis.

$$
\mathrm{EJS}=\beta_{0+} \beta_{1} \mathrm{JDE}+\beta_{2} \mathrm{~T} \& \mathrm{D}+\beta_{3} \mathrm{WLB}+\beta_{4} \mathrm{C} \& \mathrm{R}+\beta_{5} \mathrm{WENV}+\mathrm{e}_{\mathrm{it}}
$$

Where, EJS = Employee job satisfaction; JDE = Job design; T\&D = Training and development; $\mathrm{WLB}=$ Work life balance $\mathrm{C} \& \mathrm{R}=\mathrm{Compensation}$ and reward; $\mathrm{WENV}=$ Workplace environment; $\mathrm{e}_{\mathrm{it}}=$ error term and $\beta_{1,} \beta_{2^{\prime}} \beta_{3^{\prime}} \beta_{4}$ and $\beta_{5}$ are the beta coefficients of the explanatory variables to be estimated.

\section{Results and Discussion}

\section{Correlation analysis}

On analysis of data, correlation analysis has been undertaken first and for this purpose Pearson's correlation coefficients have been computed and the results are presented in the following table.

Table 1: Pearson's correlation coefficient matrix on quality of work life linkage with job satisfaction in Nepalese Commercial Banks

This table presents the correlation between dependent variable.JS (job satisfaction is the how an employee feels about the experience with job performance at work place) is the dependent variable. The independent variables are WE(work place environment refers to the location where task is completed), WLB (work life balance is defined as scheduling time for work and personal activities usually unrewarding), CAR (compensation and rewards refer to the payment made in monetary or non-monetary term against contribution made by an employee in an organization), TAD (training and development refers to exercise and practice to employees to enhance their knowledge and skill at work place) and JD(job design refers to allocation and combination of various relevant task under particular job title so as to achieve responsibility-job description match).

\begin{tabular}{|l|c|r|l|l|l|l|l|l|}
\hline Variables & Mean & Std. Deviation & WE & WLB & CAR & TAD & JD & JS \\
\hline WE & 3.9112 & 0.79352 & 1 & & & & & \\
\hline WLB & 3.9013 & 0.78132 & $0.756^{* *}$ & 1 & & & & \\
\hline CAR & 3.8610 & 0.79125 & $0.731^{* *}$ & $0.781^{* *}$ & 1 & & & \\
\hline TAD & 3.9815 & 0.75001 & $0.607^{* *}$ & $0.769^{* *}$ & $0.763^{* *}$ & 1 & & \\
\hline JD & 3.8802 & 0.76125 & $0.755^{* *}$ & $0.823^{* *}$ & $0.787^{* *}$ & $0.804^{* *}$ & 1 & \\
\hline JS & 3.9115 & 0.69012 & $0.780^{* *}$ & $0.700^{* *}$ & $0.651^{* *}$ & $0.593^{* *}$ & $0.639^{* *}$ & 1 \\
\hline
\end{tabular}

** Correlation is significant at the 0.01 level (2-tailed).

The results show that there is positive relationship of working environment with job satisfaction which indicates that better the working environment, higher would be the job satisfaction. Likewise, the study observed positive relationship between work life balance 
and job satisfaction indicating that the higher level of work life balance, higher would be the job satisfaction. Similarly, the positive relationship between compensation and reward and job satisfaction reveals that higher compensation and reward leads to an increase in the job satisfaction of employees of commercial banks. The result shows that training and development and job satisfaction are positively correlated, which indicates that effective training, and development leads to higher job satisfaction. Lastly, the result shows that there is positive correlation between job design and job satisfaction, which indicates higher the level of job satisfaction, higher would be the job satisfaction.

\section{Regression analysis}

Table 2 presents the regression results of work environment, work life balance, compensation and training, training and development and job design employee job performance of Nepalese commercial banks.

Table 2: Estimated regression result of job design, compensation and reward, work life balance, training and development and working environment on job satisfaction in Nepalese Commercial Banks.

The results are based on the data from 25 sample commercial banks with 225 observations by using linear regression model. The model is $\mathrm{JS}=\beta_{0}+\beta_{1} \mathrm{WE}+\beta_{2} \mathrm{WLB}+\beta_{3} \mathrm{CAR}+\beta_{4}$ TAD $+\beta 5$ JD where JS (job satisfaction is the how an employee feels about the experience with job performance at work place) is the dependent variable. The independent variables are WE(work place environment refers to the location where task is completed), WLB (work life balance is defined as scheduling time for work and personal activities usually unrewarding), CAR (compensation and rewards refer to the payment made in monetary or non-monetary term against contribution made by an employee in an organization), TAD (training and development refers to exercise and practice to employees to enhance their knowledge and skill at work place) and JD(job design refers to allocation and combination of various relevant task under particular job title so as to achieve responsibility-job description match)The reported results also include the values of F-statistics (F), adjusted coefficient of determination $\left(\mathrm{R}^{2}\right)$ and standard error of estimates (SEE).

\begin{tabular}{|c|c|c|c|c|c|c|c|c|c|}
\hline \multirow{2}{*}{ Model } & \multirow{2}{*}{ Intercept } & \multicolumn{5}{|c|}{ Regression coefficients of } & \multirow{2}{*}{$\begin{array}{c}\text { Adj. R } \\
- \text { bar }^{2}\end{array}$} & \multirow{2}{*}{ SEE } & \multirow{2}{*}{ F-value } \\
\hline & & WE & WLB & CAR & TAD & JD & & & \\
\hline 1 & $\begin{array}{l}1.252 \\
(5.618)^{* *}\end{array}$ & $\begin{array}{l}0.6781 \\
(12.16)^{* *}\end{array}$ & & & & & 0.599 & 0.43651 & 147.431 \\
\hline 2 & $\begin{array}{l}1.551 \\
(6.270)^{* *}\end{array}$ & & $\begin{array}{l}0.603 \\
(9.731)^{* *}\end{array}$ & & & & 0.487 & 0.48 & 94.671 \\
\hline 3 & $\begin{array}{l}1.721 \\
(6.547)^{\star *}\end{array}$ & & & \begin{tabular}{|l|}
0.568 \\
$(8.511)^{\star *}$
\end{tabular} & & & 0.420 & 0.52381 & 72.402 \\
\hline 4 & \begin{tabular}{|l}
1.729 \\
$(5.722)^{\star *}$
\end{tabular} & & & & \begin{tabular}{|l|}
0.548 \\
$(7.324)^{* *}$
\end{tabular} & & 0.346 & 0.55551 & 53.501 \\
\hline
\end{tabular}




\begin{tabular}{|l|l|l|l|l|l|l|l|l|l|}
\hline 5 & $\begin{array}{l}1.678 \\
(6.048)^{* *}\end{array}$ & & & & $\begin{array}{l}0.577 \\
(8.193)^{* *}\end{array}$ & 0.401 & 0.53219 & 67.099 \\
\hline 6 & $\begin{array}{l}1.043 \\
(4.589)^{* *}\end{array}$ & $\begin{array}{l}0.503 \\
(6.079)^{* *}\end{array}$ & $\begin{array}{l}.233 \\
(2.824)^{* *}\end{array}$ & & & & 0.623 & 0.42129 & 83.239 \\
\hline 7 & $\begin{array}{l}1.009 \\
(4.347)^{* *}\end{array}$ & $\begin{array}{l}0.484 \\
(5.559)^{* *}\end{array}$ & $\begin{array}{l}.196 \\
(2.011)^{*}\end{array}$ & $\begin{array}{l}0.063 \\
(.689)\end{array}$ & & & 0.623 & 0.42239 & 55.349 \\
\hline 8 & $\begin{array}{l}9390 \\
(3.780)^{* *}\end{array}$ & $\begin{array}{l}0.487 \\
(5.594)^{* *}\end{array}$ & $\begin{array}{l}0.160 \\
(1.491)\end{array}$ & $\begin{array}{l}0.331 \\
(0.324)\end{array}$ & $\begin{array}{l}0.781 \\
(0.792)\end{array}$ & & 0.620 & 0.42320 & 41.513 \\
\hline 9 & $\begin{array}{l}9472 \\
(3.809)^{* *}\end{array}$ & $\begin{array}{l}0.522 \\
(5.669)^{* *}\end{array}$ & $\begin{array}{l}0.189 \\
(1.751)\end{array}$ & $\begin{array}{l}0.049 \\
(0.488)\end{array}$ & $\begin{array}{l}0.128 \\
(1.181)\end{array}$ & $\begin{array}{l}-0.137 \\
(-1.130)\end{array}$ & 0.623 & 0.42264 & 33.559 \\
\hline
\end{tabular}

Notes: Figures in parentheses are t- values.

The asterisk signs $\left(^{* *}\right)$ and $\left(^{*}\right)$ indicate that the results are significant at 1 percent and 5 percent level respectively.

Table 2 presents that beta coefficient is positive and significant for working environment. It indicates that working environment has positive impact on job satisfaction. This finding is similar to the findings of Khan and Mishra (2013). Similarly, the beta coefficient is positive and significant for work life balance. This means the work life balance has positive impact on the job satisfaction on commercial banks. This finding is similar to the findings of Adikaram and Javatilake (2016).

Likewise, the result shows that beta coefficient is positive and significant for compensation and reward, which indicates that the compensation and rewards have positive impact on job satisfaction on commercial banks. This finding is similar to the findings of Danish and Ushman (2010). Similarly, beta coefficient is positive for training and development. It indicates that the training and development has positive impact on the job satisfaction. This finding is similar to the findings of Anwar and Shukur (2015). Lastly, the result shows that beta coefficient is positive for job satisfaction on commercial banks. It indicates that the job design has positive impact on the job satisfaction. This finding is similar to the findings of Abid et al. (2013).

\section{Conclusion}

The study concludes that the work life balance, compensation and reward, training and development, job design factor also play a major role in job satisfaction of Nepalese commercial bank. As organizations have become more focused on QWL due to high competition they are keeping all the factors in mind and only through the evaluation they are evaluating the job satisfaction. Through this research, we can say that job satisfaction has created influence by some of its independent factors (i.e. work environment, work life balance, compensation and reward, training and development, job design). The study shows that work life balance and workplace environment have positive impact on the job satisfaction. Similarly, the result shows that there is positive impact of training and development on the job satisfaction. The study also reveals that the compensation and rewards have positive impact on the job satisfaction. Likewise, the study shows that job design has positive impact on the job satisfaction. The study also concludes that work place environment followed by work life balance and compensation and rewards are the most influencing factors to determine employees' job satisfaction in Nepalese commercial banks. 


\section{References}

Abid, A. M., Sarwar, A., Imran, K., Jabbar, A. \& Hannan, A. (2013). Effect of job design on employee satisfaction (a study of fertilizer companies listed in Lahore Stock Exchange). European Journal of Business and Management, 5(19), 1-7.

Adikaram, D. S. R., \& Jayatilake, L. (2016). Impact of work life balance on employee job satisfaction in private sector commercial banks of Sri Lanka. International Journal of Scientific Research and Innovative Technology, 3(11), 18-33.

Akdere, M. (2006). Improving quality of work-life: Implications for human resources. The Business Review, 6(1), 173-177.

Almarshad, S. O. (2015). Municipal awareness and citizen satisfaction: The case of the northern borders in Saudi Arabia. International Review of Management and Marketing, 5(2), 94101.

Almalki, M. J., FitzGerald, G., Clark, M. (2012). Quality of work life among primary health care nurses in the Jazan region, Saudi Arabia: a cross-sectional study. Human Resources for Health, 10(1), 30.

Anwar, G., \& Shukur, I. (2015). The Impact of Training and Development on Job Satisfaction: A Case Study of Private Banks in Erbil. International Journal of Social Sciences \& Educational Studies, 2(1), 65.

Aslam, A., Ghaffar, A. Talha, T., \& Mushtaq, H. (2015). Impact of compensation and reward system on the performance of an organization: An empirical study on banking sector of Pakistan. European Journal of Business and Social Sciences, 4(8), 319-325.

Black, S. E., \& Lynch, L. M. (2001). How to compete: The impact of workplace practices and information technology on productivity. Review of Economics and Statistics, 82(1), 434445.

Costen, W. M., \& Salazar, J. (2011). The impact of training and development on employee job satisfaction, loyalty, and intent to stay in the lodging industry. Journal of Human Resources in Hospitality \& Tourism, 10(3), 273-284.

Danish, R. Q., \& Usman, A. (2010). Impact of reward and recognition on job satisfaction and motivation: An empirical study from Pakistan. International journal of Business and Management, 5(2), 159.

Fatehi, B., Karimi, A., Pour, E.G., Pour, K. A., \& Azizi, B. (2015). Impact of quality of work life on job satisfaction. International Journal of Sport Studies, 5(1), 79-86.

Fourie, A. S., (2004). Predicting satisfaction with quality of work life. Master's Thesis, University of South Africa. 12-13.

Ganguly, R. (2010).Quality of work life and job satisfaction of a group of university employees. Asian Journal of Management Research. 209-216.

Golkar, H. (2013). The relationship between QWL and job satisfaction: A survey of human resource managers in Iran. Interdisciplinary Journal of Contemporary Research in Business, $5(8), 215-224$ 
Harrison, P. J., \& Jankowska, E. (1985). Organization of input to the interneurons mediating group I non-reciprocal inhibition of motoneurones in the cat. The Journal of physiology, 361(1), 403-418.

Hodgetts, R.M., Hegar, K.W. (2005). Modern Human Relations at work, 9th Ed, Thomson. South-Western, USA

Kaur, D. (2010). Quality of working life in ICICI bank ltd, Chandigarh. International Research Journal, 1(11), 29-28.

Khorsndi, M., Jahani, F., Rafiei, M., \& Farazi, A. A (2010). Arak Medical University Journal, 13(50), 40-48.

Lau, R. S.M. (2000). Quality of work life and performance: An ad hoc investigation of two key elements in the service profit chain model. International Journal of Service Industry Management, 11(5), 422 - 437.

Lawler, E. E.(1969). Job Design and Employee Motivation, Personnel Psychology, 22(1), 1969.

Lewis, D., Brazil, K., Krueger, P., Lohfeld, L., \& Tjam, E. (2001). Extrinsic and intrinsic determinants of quality of work life. Leadership in Health Service, 14 (2), 9-15.

Mirkamali, S. M., \& Sani, F. N. (2008). A study on the relationship between the quality of work life and job satisfaction among the faculty members of the university of Tehran and Sharif University of technology. Quarterly Journal of Research and Planning in Higher Education, 14(2), 71-101.

Muindi, F., \& K'Obonyo, P. (2015). Quality of work life, personality, job satisfaction, competence, and job performance: A critical review of literature. European Scientific Journal, ESJ, 11(26).

Royuela, V., López-Tamayo, J., \& Surinach, J. (2009). Results of a quality of work life index in Spain. A comparison of survey results and aggregate social indicators. Social Indicators Research, 90(2), 225-241.

Tabassum, A. (2012). Interrelations between quality of work life dimensions and faculty member job satisfaction in the private universities of Bangladesh. European journal of business and management, 4(2), 78-89.

Tabassum, A., Rahman, T. \& Jahan, K. (2011). A comparative analysis of quality of work life among the employees of local private and foreign commercial banks in Bangladesh. World Journal of Social Sciences, 1(1), 17-33.

Yaseen, A. (2013). Effect of compensation factors on employee satisfaction-a study of doctor's dissatisfaction in Punjab. International Journal of Human Resource Studies, 3(1), 142.

Yavari, U., Tash, A. A., \& Tondnevis, F. (2009). Compare the quality of working life and its subscales in the faculty of physical education colleges and public universities. Journal of Movement and Exercise Science, 7(1), 99-109. 